\title{
Studies on the Effect of Integrated Nutrient Management on Propagation of Alstromeria cv. Pink Panther through Rhizome under Nilgiris Condition
}

\author{
S. Usha*, M. Anand, M. Elayarajan, M. Ganga and A. Sankari
}

Horticultural Research Station, TNAU, The Nilgiris, India

*Corresponding author

\section{A B S T R A C T}

The present investigation was conducted to know the studies on the effect of integrated nutrient management on propagation of Alstromeria cv Pink

Keywords

Kharif season, Biofertilizers, Inorganic fertlizers

Article Info

Accepted:

04 June 2019

Available Online:

10 July 2019
Panther through rhizome under Nilgiris condition was carried out during the year 2017-2018. The experiment was laid out in a Randomized Block Design (RBD) with ten treatments. Single rhizomes were planted and in the plot area of $1 \times 1 \mathrm{~m}^{2}$ and spacing of $30 \times 30 \mathrm{~cm}$ during the Kharif season. Among the treatments days for sprout initiation (16.54 days), rhizome length $(14.36 \mathrm{~cm})$, rhizome weight $(85.12 \mathrm{~g})$, number of rhizomes $(10.67$ nos), number of storage roots $(6.87$ nos) and number of fibrous roots $(8.32$ nos) were recorded in the treatment $\mathrm{T}_{6}$. Thus it can concluded from the findings that application of $100 \% \operatorname{RDF}\left(30: 15: 30 \mathrm{~g} / \mathrm{m}^{2}\right)+$ Biofertilizers (Azospirillium $1.5 \mathrm{~g} / \mathrm{m}^{2}+$ Phosphobacteria $1.5 \mathrm{~g} / \mathrm{m}^{2}$ ) + FYM 2500 $\mathrm{g} / \mathrm{m}^{2}+750 \mathrm{~g} / \mathrm{m}^{2}$ Vermicompost) can be recommended for propagative parameters for Alstromeria under Niligris condition.

\section{Introduction}

Alstroemeria L. also known as Peruvian lily or Lily of the Incas belonging to the family Alstroemeriaceae is a potential cutflower and also a potted plant having huge demand in international trade among the cutflowers. Flowers vary in wide range of colours. With the advancement in greenhouse cultivation technologies, alstroemeria is emerging as a competitive greenhouse cutflower crop from the past two decades. Genus Alstroemeria is a well-known perennial monocot consisting of several species. Alstroemerias are rhizomatous perennials, consisting of sympodial fleshy and multi-stemmed rhizomes. The leaves are entire, grey green to dark green in colour, hairless and thick. Depending on the environmental conditions, the shoots are either reproductive or vegetative. Alstroemeria usually are of three types that are butterfly type consisting of shorter stems and peduncles, orchid types having longer stems and peduncles and most of the today's hybrids belong to the aurantiaca type which has 
intermediate length stem and peduncles.

Alstroemeria is commonly propagated by the division of rhizomes. For quick and productive crop, active growing healthy and disease free divisions are necessary. It is also done through seeds, but this is generally avoided due to variability. The aerial shoot arises from an underground sympodial rhizome attached to thick fleshy roots. The rhizomes develop into vertical shoots and later generate lateral rhizomes which also produce flowering shoots.

Major cultivation of alstroemeria is found in Netherlands occupying around 110 hectare and total area in the world accounts for 400 hectare. In India majority of alstroemeria is cultivated in hilly regions of Himachal Pradesh and Jammu and Kashmir. In southern part of India in Tamil Nadu Nilgirisis well known for alstroemeria cultivation where production contributes around 58.60 lakh stems under 5.86 hectare area.

Nutrition plays essential role in crop growth. Application of adequate nutrients at required quantity at the destined time period is highly important as it affects the crop production. Soil fertility deterioration and loss of soil quality caused by use of inorganic fertilization consisting on chemical based fertilizer application can be substituted by organic fertilizers composed of organic wastes from plant and animal residues which are renewable and also promotes soil health. Use of chemicals alone might result in environmental hazards that might result in imbalance in the ecosystem. Henceforth sustainable method such as integrated nutrient application has been highly recommended.

Alstroemeria an uprising crop in cutflower industry has sparse information regarding the nutritional requirement. Due to the lack of experimental evidence on the response of alstroemeria to the inorganic nutrition and organic nutrients on productivity potential and quality of alstroemeria, this research was concentrated more on integrated nutrient management in alstroemeria

\section{Materials and Methods}

The present investigation was carried out during the year 2017-2018 to study the effect of integrated nutrient management on propagation of Alstromeriacv Pink Panther through rhizome under Nilgiris condition. The experiment was conducted in Horticultural Research Station, TNAU, The Nilgiris which is located at $11.4025^{\prime} \mathrm{N}$ Latitude, $76.735^{\prime} \mathrm{E}$ Longitude and at an Altitude of $2635 \mathrm{~m}$ above Mean Sea Level. The mean annual rainfall of The Nilgiris is $1632 \mathrm{~mm}$. The average maximum and minimum temperature is $26.0^{\circ} \mathrm{C}$ and $2^{\circ} \mathrm{C}$ respectively. The average relative humidity is 75 per cent. The experiment was laid out in a Randomized Block Design (RBD) with ten treatments replicated thrice and treatment details are furnished in table 1. The Alstromeria rhizomes were divided and healthy rhizomes were selected from mother block. Single rhizomes were planted and in the plot area of $1 \mathrm{x} 1 \mathrm{~m}^{2}$ and spacing of 30x30 cm. All organic manures like Farm Yard Manure (FYM), Vermicompost (VC) and bio-fertilizers viz., Azospirillum and phosphorus solubilizing bacteria applied as per the treatment. $\mathrm{N}$ applied as basal at the time of planting and remaining $50 \% \mathrm{~N}$ was applied in splits at 45 days after planting. One third of $\mathrm{P}$ and $\mathrm{K}$ applied at the time of planting and remaining splits were applied at every three months interval as per the treatments. In each replication five plants were selected for recording biometrics observations on days for sprout initiation, rhizome length, rhizome weight, number of rhizomes, number of storage roots and number of fibrous roots. The data generated during the course of study was 
subjected to statistical analysis as prescribed by Panse and Sukhatme (2000).

\section{Results and Discussion}

The propagative characters of alstroemeria are very much important as they play a key role in deciding the vegetative and the reproductive growth contributing to the ultimate crop yield. These parameters differed among the various treatments and results indicated that significant variation was observed among the treatments for all the characters were presented in table 2 .

The earliest sprouting was noticed from 16.54 days in the treatment $\mathrm{T}_{6}$ and the treatment $\mathrm{T}_{10}$ recorded the late sprout initiation of 20.22 days. FYM and vermicompost are very good insulating agents and these constituents have a higher temperature comparatively. This higher temperature could be the reason for early sprouting. Relatively, FYM have a high water retention capacity. The continued availability of moisture in the FYM helped the rhizome sections to sprout earlier by allowing cells at the growing point to expand rapidly. These findings are in accordance with the reports of Gupta et al., (2008) in gladiolus.

Number of rhizomes per plant is one of the most prominent characters, since it has an active role in storage of assimilates and propagative material of the crop. The treatment $\mathrm{T}_{6}$ produced more number of rhizomes (10.67nos) followed by $T_{5}$ (10.12nos). The number of rhizomes formed depends upon the time of initiation of branching. Media with organic base allow a head start for new above ground growth which in turn provides photosynthates for underground organs. This early initiation of new rhizome allows more time for branching and hence, more number of rhizomes at the harvest. This increase in the mineral constituents might have exerted more number of leaves, since nitrogen is the chief constituent of amino acid and coenzymes of biological importance. This is in concurrence with the findings Singh et al., (2014) in tuberose.

Table.1 Treatment details

\begin{tabular}{|c|c|}
\hline $\mathbf{T}_{\mathbf{1}}$ & $\begin{array}{l}\left.\text { 150\% RDF (45:30:45 N:P:K } \mathrm{g} / \mathrm{m}^{2}\right)+ \text { Biofertilizers (Azospirillium } 1.5 \mathrm{~g} / \mathrm{m}^{2}+ \\
\left.\text { Phosphobacteria } 1.5 \mathrm{~g} / \mathrm{m}^{2}\right)\end{array}$ \\
\hline $\mathbf{T}_{2}$ & 150\% RDF (45:30:45 N:P:K g/m²)+FYM $2500 \mathrm{~g} / \mathrm{m}^{2}+750 \mathrm{~g} / \mathrm{m}^{2}$ Vermicompost \\
\hline $\mathbf{T}_{\mathbf{3}}$ & $\begin{array}{l}150 \% \text { RDF }\left(45: 30: 45 \mathrm{~N}: \mathrm{P}: \mathrm{K} \mathrm{g} / \mathrm{m}^{2}\right)+\text { Biofertilizers (Azospirillium } 1.5 \mathrm{~g} / \mathrm{m}^{2}+ \\
\left.\text { Phosphobacteria } 1.5 \mathrm{~g} / \mathrm{m}^{2}\right)+\mathrm{FYM} 2500 \mathrm{~g} / \mathrm{m}^{2}+750 \mathrm{~g} / \mathrm{m}^{2} \text { Vermicompost }\end{array}$ \\
\hline $\mathbf{T}_{4}$ & $\begin{array}{l}100 \% \text { RDF }\left(30: 15: 30 \mathrm{~g} / \mathrm{m}^{2}\right)+\text { Biofertilizers (Azospirillium } 1.5 \mathrm{~g} / \mathrm{m}^{2}+\text { Phosphobacteria } \\
\left.1.5 \mathrm{~g} / \mathrm{m}^{2}\right)\end{array}$ \\
\hline $\mathbf{T}_{5}$ & $100 \%$ RDF $\left(30: 15: 30 \mathrm{~g} / \mathrm{m}^{2}\right)+$ FYM $2500 \mathrm{~g} / \mathrm{m}^{2}+750 \mathrm{~g} / \mathrm{m}^{2}$ Vermicompost \\
\hline $\mathbf{T}_{6}$ & $\begin{array}{l}100 \% \text { RDF }\left(30: 15: 30 \mathrm{~g} / \mathrm{m}^{2}\right)+\text { Biofertilizers (Azospirillium } 1.5 \mathrm{~g} / \mathrm{m}^{2}+\text { Phosphobacteria } \\
\left.1.5 \mathrm{~g} / \mathrm{m}^{2}\right)+ \text { FYM } 2500 \mathrm{~g} / \mathrm{m}^{2}+750 \mathrm{~g} / \mathrm{m}^{2} \text { Vermicompost }\end{array}$ \\
\hline $\mathbf{T}_{7}$ & $50 \%$ RDF $\left(15: 7.5: 15 \mathrm{~g} / \mathrm{m}^{2}\right)+\left(\right.$ Azospirillium $1.5 \mathrm{~g} / \mathrm{m}^{2}+$ Phosphobacteria $\left.1.5 \mathrm{~g} / \mathrm{m}^{2}\right)$ \\
\hline $\mathbf{T}_{8}$ & $50 \%$ RDF $\left(15: 7.5: 15 \mathrm{~g} / \mathrm{m}^{2}\right)+$ FYM $2500 \mathrm{~g} / \mathrm{m}^{2}+750 \mathrm{~g} / \mathrm{m}^{2}$ Vermicompost \\
\hline $\mathbf{T}_{9}$ & $\begin{array}{l}50 \% \text { RDF }\left(15: 7.5: 15 \mathrm{~g} / \mathrm{m}^{2}\right)+\text { Biofertilizers (Azospirillium } 1.5 \mathrm{~g} / \mathrm{m}^{2}+\text { Phosphobacteria } \\
\left.1.5 \mathrm{~g} / \mathrm{m}^{2}\right)+ \text { FYM } 2500 \mathrm{~g} / \mathrm{m}^{2}+750 \mathrm{~g} / \mathrm{m}^{2} \text { Vermicompost }\end{array}$ \\
\hline $\mathbf{T}_{10}$ & Recommended dose of fertilizers N:P:K $\left(30: 15: 30 \mathrm{~g} / \mathrm{M}^{2}\right)$ Control \\
\hline
\end{tabular}


Table.2 The effect of integrated nutrient management on propagative characteristics of Alstroemeria

\begin{tabular}{|c|c|c|c|c|c|c|}
\hline Treatments & $\begin{array}{c}\text { Days for } \\
\text { sprout } \\
\text { initiation }\end{array}$ & $\begin{array}{c}\text { Rhizome } \\
\text { length }\end{array}$ & $\begin{array}{c}\text { Rhizome } \\
\text { weight }\end{array}$ & $\begin{array}{c}\text { Number } \\
\text { of } \\
\text { rhizomes }\end{array}$ & $\begin{array}{c}\text { Number } \\
\text { of } \\
\text { storage } \\
\text { roots }\end{array}$ & $\begin{array}{c}\text { Number } \\
\text { of } \\
\text { fibrous } \\
\text { roots }\end{array}$ \\
\hline T1 & 20.15 & 12.31 & 65.17 & 8.26 & 3.38 & 4.71 \\
\hline T2 & 18.32 & 12.42 & 66.32 & 8.54 & 4.52 & 5.21 \\
\hline T3 & 18.62 & 12.81 & 73.46 & 8.10 & 5.20 & 5.14 \\
\hline T4 & 19.14 & 13.52 & 75.28 & 9.20 & 4.46 & 5.28 \\
\hline T5 & 16.78 & 14.12 & 82.35 & 10.12 & 6.42 & 7.69 \\
\hline T6 & 16.54 & 14.36 & 85.12 & 10.67 & 6.87 & 8.32 \\
\hline T7 & 17.12 & 13.75 & 76.18 & 9.40 & 6.10 & 5.32 \\
\hline T8 & 18.65 & 12.21 & 72.51 & 8.80 & 4.60 & 5.24 \\
\hline T9 & 17.47 & 11.96 & 68.72 & 8.60 & 4.90 & 5.16 \\
\hline T10 & 20.22 & 11.32 & 63.56 & 8.16 & 3.25 & 4.11 \\
\hline Mean & $\mathbf{1 8 . 3 0}$ & $\mathbf{1 2 . 8 7}$ & $\mathbf{7 2 . 8 6}$ & $\mathbf{8 . 9 4}$ & $\mathbf{4 . 9 7}$ & $\mathbf{5 . 6 1}$ \\
\hline SEd & $\mathbf{0 . 2 4}$ & $\mathbf{0 . 0 7}$ & $\mathbf{0 . 5 1}$ & $\mathbf{0 . 0 7}$ & $\mathbf{0 . 0 5}$ & $\mathbf{0 . 1 0}$ \\
\hline CD(0.05) & $\mathbf{0 . 4 8}$ & $\mathbf{0 . 1 5}$ & $\mathbf{1 . 1 0}$ & $\mathbf{0 . 1 4}$ & $\mathbf{0 . 1 2}$ & $\mathbf{0 . 2 0}$ \\
\hline
\end{tabular}

The highest rhizome length was produced in $\mathrm{T}_{6}(14.36 \mathrm{~cm})$ followed by $\mathrm{T}_{5}(14.12 \mathrm{~cm}) \mathrm{T}_{7}$ $(13.75 \mathrm{~cm})$ and $\mathrm{T}_{10}(11.32 \mathrm{~cm})$ which recorded the lowest rhizome length during the experimental period. Biofertilizers provide favourable environment for underground storage organs that allows unhindered extension of the new rhizomes. This is because of the low bulk density of the organic matter mixtures which keeps the medium light and porous for rhizome development. The present findings are in agreement with the observations of Ahmad Ali et al., (2014) in gladiolus. The maximum rhizome weight of $(85.12 \mathrm{~g})$ was registered in the $\mathrm{T}_{6}$ followed by $\mathrm{T}_{5}(82.35 \mathrm{~g})$ while $\mathrm{T}_{10}$ recorded the minimum weight of $(63.56 \mathrm{~g})$. The biofertilizers especially Azospirillum due to their physico-chemical properties enhanced the formation of fleshy storage roots which accumulated more nutrients and water and ultimately increased the weight of the rhizome cluster. These findings are in accordance with Gupta and Gupta (2007) in
Alstroemeria. The storage and fibrous roots together constitute the root system of the alstroemeria. Storage roots mostly develop into rhizomelets and fibrous roots helps in the crop stand. The development of the roots was significantly influenced by the application of organic and inorganic manures. The maximum number of storage roots ranged from 3.25 to 6.87 . The maximum number of storage roots was recorded in the treatment $\mathrm{T}_{6}$ of 6.87 nos whereas the minimum number of storage roots 3.25 nos was recorded in the treatment $\mathrm{T}_{10}$. With respect to the number of fibrous roots, maximum number of fibrous roots was noticed in the treatment $T_{6}$ of 8.32 nos followed by treatments $T_{5}$ which showed 7.69 nos. $\mathrm{T}_{10}$ (control) recorded the minimum number of fibrous roots of 4.11 nos. Rhizomes provided with biofertilizers have stored more carbohydrates through effective photosynthesis. The increase in root spread might be due to storage of carbohydrates and nitrogen compounds in the rhizomes. The carbohydrates and soluble nitrogen 
compounds translocate from leaves to rhizomes that helps in the formation of new rhizomelets and allows better root spread. This is in concurrence with the findings of Singh et al., (2014) in alstroemeria. The results of the present investigation thus revealed that among the 10 treatments Alstromeria $c v$ pink panther species $\mathrm{T}_{6}(100$ $\%$ RDF $\left(30: 15: 30 \mathrm{~g} / \mathrm{m}^{2}\right)+$ Biofertilizers (Azospirillium $1.5 \mathrm{~g} / \mathrm{m}^{2}+$ Phosphobacteria $\left.1.5 \mathrm{~g} / \mathrm{m}^{2}\right)+$ FYM $2500 \mathrm{~g} / \mathrm{m}^{2}+750 \mathrm{~g} / \mathrm{m}^{2}$ Vermicompost) performed better in terms of propagative characters for Alstroemeria under Nilgiris condition

\section{References}

Ahmad Ali, Tahir mehmood, Rashid Hussain, Ajmal Bashir, Sajjad Raza, Najam-udDin and Adeel Ahmad, 2014. Investigation of biofertilizers influence on vegetative growth, flower quality, bulb yield and nutrient uptake in gladiolus (Gladiolus grandiflorus L.). International Journal of Plant, Animal and Environmental Sciences, Vol 4: Issue 1.

Gupta, P., Rajwal, N., Dhaka, V.K. and Rajwal, D. (2008). Effect of different levels of vermicompost, NPK and FYM on performance of gladiolus (Gladiolus grandiflorus). Asian J. Hort., 3(1): 142143.

Gupta, R. and Gupta, Y.C. (2007). Effect of rhizome portions and growing media on establishment of plants and shoot production in Alstroemeria (Alstroemeria hybrids). J. Orna. Hort., 10(3): 161-164.

Singh, Arvinder, Nazki, Imtiyaz Tahir, Qadri, Zahoor Ahmad and Ahmad, Zahoor (2014). Effect of propagation media on clonal propagation through rhizome sections in Alstroemeria cv. 'SERENA'. Asian J. Hort., 9(1): 213-216.

Singh, D. Singh, V.K., Kumari, S. Pandey, S.K. and D. Singh, 2014. Response of different levels of NPK on growth, flowering and yield of tuberose (Polianthes tuberosa L.) cv. Shringar. New Agriculturist, 25: 1-5

V. G, Panse, P.V, Sukhatme. 2000. Statistical methods for agricultural workers. Publication and Information Division of ICAR, New Delhi.

\section{How to cite this article:}

Usha, S., M. Anand, M. Elayarajan, M. Ganga and Sankari, A. 2019. Studies on the Effect of Integrated Nutrient Management on Propagation of Alstromeria cv. Pink Panther through Rhizome under Nilgiris Condition. Int.J.Curr.Microbiol.App.Sci. 8(07): 259-263. doi: https://doi.org/10.20546/ijcmas.2019.807.033 